\title{
Keep older healthcare workers off the covid-19 front line
}

\author{
John Ashcroft general practitioner
}

Ilkeston, UK

Even with appropriate personal protective equipment, coronavirus infections will occur. ${ }^{1}$ Clearly, the greatest risk factor for serious illness and death is increasing age. Being male also seems to be a risk factor. ${ }^{2}$

Compared with people in their 20s or 30s, those of us in our 50 s or 60 s have a likelihood of death from covid-19 that is an order of magnitude higher. In Italy, most of the 74 doctors who have died were in their 60 s, and only four were women. ${ }^{3}$

In light of this, the NHS should ensure that only younger doctors, nurses, and other staff are "patient facing." Older staff should recognise their inherent risks and be prepared to let the next generation take the front line whenever possible.

Competing interests: I am an older, male GP.

1 Godlee F. Protect our healthcare workers. Editor's choice. BMJ 2020;369:m132.

Age, sex, existing conditions of covid-19 cases and deaths. https://www.worldometers. info/coronavirus/coronavirus-age-sex-demographics/

3 Reguly E. Italian doctors' fatalities reach tragic levels as they fight COVID-19 in overburdened hospitals. Globe and Mail 2020 Apr 3. https://www.theglobeandmail.com/ world/article-italian-doctors-fatalities-reach-tragic-levels-as-they-fight-covid-1/

Published by the BMJ Publishing Group Limited. For permission to use (where not already granted under a licence) please go to http://group.bmj.com/group/rights-licensing/ permissions 